\title{
Geo-Hydrodynamics of Bagjata Area and its Significance with Respect to Seasonal Fluctuation of Groundwater
}

\author{
Bijay Singh ${ }^{1}$, A. S. Singh ${ }^{2}$ \\ ${ }^{1}$ University Department of Geology, Ranchi University, Ranchi, India \\ ${ }^{2}$ National Mineral Development Corporation Limited, Kirandul Complex, Chhattisgarh, India \\ E-mail: bsingh6029@gmail.com, ajayshekhar1@rediffmail.com \\ Received February 2, 2010; revised March 25, 2010; accepted May 26, 2010
}

\begin{abstract}
Bagjata area is a part of Singhbhum Shear Zone (SSZ) falling within Survey of India Toposheets No. 73J/6, $\mathrm{J} / 7, \mathrm{~J} / 10$ and $\mathrm{J} / 11$. The Subarnarekha River, Sankh Nala and Gohala faults are major discontinuities in the area. An attempt has been made to simulate the regional groundwater hydrodynamics. Few dug-wells were monitored for more than a year to find out the seasonal fluctuation changes in the drainage pattern and groundwater level. Groundwater samples were analyzed for physical and chemical analysis. Results show that one of the major discontinuities in the area - the Gohala Fault controls largely the geohydrodynamics of the area. Discharge of groundwater is of effluence type during all the three seasons. The water is safe for drinking as most of the contaminations are much below the permissible limits. No such previous work has been attempted in this area to investigate the groundwater dynamics and hence the selection of few parameters were assumed and taken from similar surrounding aquifer systems for modeling. The groundwater flow was also assumed to be in steady state. The present paper deals with some important aspects related to the hydrological significance of the Bagjata Uranium mining area and its relationship with the local climate, physiography and meteorology. An attempt is also made to simulate the status of groundwater conditions of hard rock aquifers in the region. Further it envisages the necessity of such study being undertaken in the entire SSZ belt to secure precise information about the surface manifestations which govern the groundwater recharge potentiality as well as its quality.
\end{abstract}

Keywords: Geo-hydrodynamics, Bagjata Groundwater, Singhbhum Shear Zone (SSZ), Gohala Fault, Effluence, Uranium-Copper Mineralization

\section{Introduction}

Bagjata is located in Dalbhumgarh subdivision of East Singhbhum district of Jharkhand state at a distance of about $6.5 \mathrm{~km} \mathrm{SE}$ of the copper mining town of Musabani. The nearest Railway station is Dalbhumgarh. It can also be accessed by road from Jamshedpur and Jaduguda townships. The geohydrological significance in this area is important due to various misconceptions about the contamination of radiogenic contents in the water bodies of the entire Uranium belt. No such previous information / data are available for this area to allay the fears of local populace. This work assumes importance as being the first attempt of its kind in the SSZ. During the research important aspects of groundwater and its movement within aquifers have been studied vis-à-vis the geological setting of the area. It was noticed carefully and found to be very much linked with the subsurface water transport mechanism and the quality and its ground water. The investigation includes planning, sample collection, analytical chemistry, quality and data management. The sub surface water was routinely analyzed, geohydrodynamics discussed and modeling studies done on the basis of the well inventory data.

\section{Materials and Methods}

The Bagjata area is confined to the sheared rock types of Singhbhum Thrust Zone. Geologically, the thrust belt is constituted by Archaean metasediments such as mica-schist, quartzite, phyllites and altered tuffs. During the field mapping authors find the rock formation trending along NW-SE with variable dip of $35^{\circ}$ to $45^{\circ}$ due North-East. The shear zone has been a major 


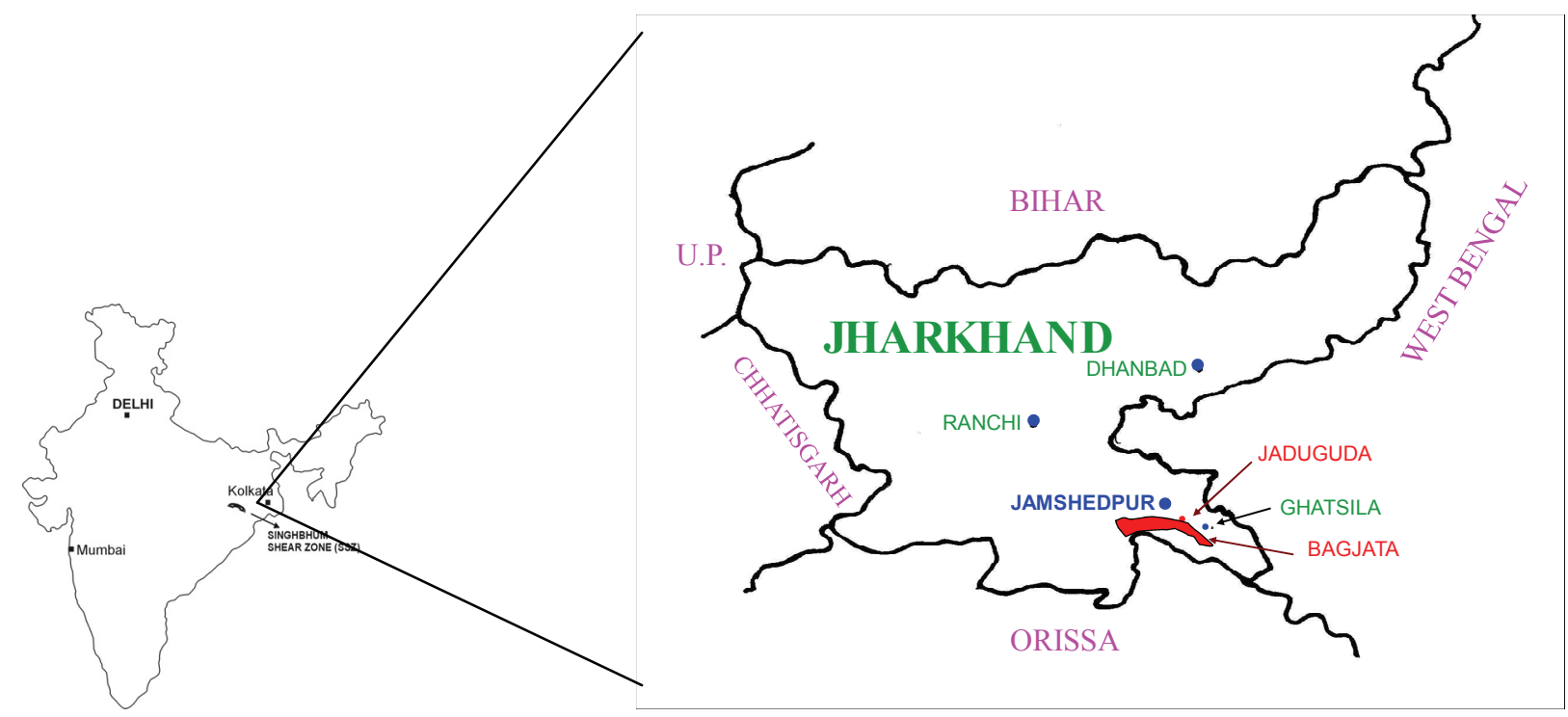

Figure 1. Location of bagjata area, east Singhbhum, Jharkhand, India.

site for intense mineralization in the region.

The geological mapping in the area was carried out with the help of GPS and other traditional field equipments in order to investigate an area falling under four SOI toposheets integrated with the help of Surfer 8.0 and AutoCAD software followed by intensive groundtruthings.

The principle planar structures at Bagjata are foliation planes, joint planes and shear planes. The foliation planes are the dominant planar feature in the rocks. There are three sets of joint planes present in the rocks.

$\mathrm{J}-1$ :- The most prominent one is nearly parallel to foliation strike but having dips of $30^{\circ}$ to $50^{\circ}$ towards SW (opposite to the Uranium lode). A few of them are nearly vertical.

$\mathrm{J}-2$ : - The second set of joints is the dip joints which are vertical or having dips of $30^{\circ}$ to $50^{\circ}$ towards NW or SE.

$\mathrm{J}-3$ :- In general this is not prominent, but present at places with variable directions.

On the basis of field investigations, authors find the area with a gentle to moderately steep or steep slopes. The selected area is to the north and west of a small hill range. The ground level of the area is at 120-144 m RL whereas hilltops to the east are at about $300 \mathrm{~m} \mathrm{RL}$ and those to the south are mostly at $350-400 \mathrm{~m} \mathrm{RL}$. There is another hill range which is within the study zone. These hills are however, less steep and made up of quartzite. General ground level gradually slopes towards the North. The NE quadrant of the area is blocked by Gohala Fault. The natural drainage system is dendritic in nature due to hilly topography and well defined gradients in parts of the study area. The area is very important in terms of lithology and hydrogeological characteristics.
The River Subarnarekha flows from the NW to the SE to the northeast part. The area lies in a valley of about 5 $\mathrm{km}$ wide extending in the NW to SE direction. This valley is drained by the Sankh Nalla, which flows northeastern part of the study area and joined the Subarnarekha River 5 $\mathrm{km}$ northeast of the Bagjata. Major part of the area has a dendritic drainage pattern.

The hill ranges are drained by seasonal streams which form the part of the Subarnarekha River System. The Sankh Nalla receives water through streams flowing down from the hills on both its banks. High flood level of the Sankh Nalla and Subarnarekha River is well below the study area.

The area lies in tropical region where climate is characterized by very hot summer and cold winter. Summer is typically from mid March to mid June when temperature ranges from $44^{\circ} \mathrm{C}$ in day to $19^{\circ} \mathrm{C}$ in night. Eighty percent of the rainfall occurs during period from mid June to mid September. The average rainfall in the region is $1391 \mathrm{~mm}$ as recorded by IMD observatory at Jamshedpur. This paper describes the fluctuations of Ground water with seasons and responses with respect to recharge/discharge.

The Geological map was prepared on the basis of field investigations with the help of a modern GPS system. Existing wells were selected for sampling and plotted on this map with the help of AutoCAD software (Figure 2). The selected wells were observed for a period more than a year and data for depth of water level are collected during all the three seasons. The depth to water level data with respect to mean sea level (Table 2) and ground water level contours has been prepared to ascertain the general groundwater hydraulic gradient. An application 
Table 1. Litho-Stratigraphic sequence.

\begin{tabular}{cll}
\hline Group & Formation & \multicolumn{1}{c}{ Lithological Units } \\
\hline & & Garnetiferous mica schist with basic and ultra basic intrusives. \\
& Chaibasa & Sericite schist. \\
Formation & Quartzite and Quartz schist. \\
& Sericite schist with impersistent Quartz-kyanite-granulite. \\
& Shear Zone & Banded Quartz-sericite-biotite schist with bands of metabasic \\
Assemblages & and Quartz-tourmaline-magnetite rock. \\
& Quartz-biotite-chlorite schist with bands of Quartzite. \\
& Quartz and sheared Conglomerate. \\
& Bhanjori & Biotite schist and Quartzite \\
& Formation & Talc schist. \\
& Traps and Quartzite. \\
&
\end{tabular}

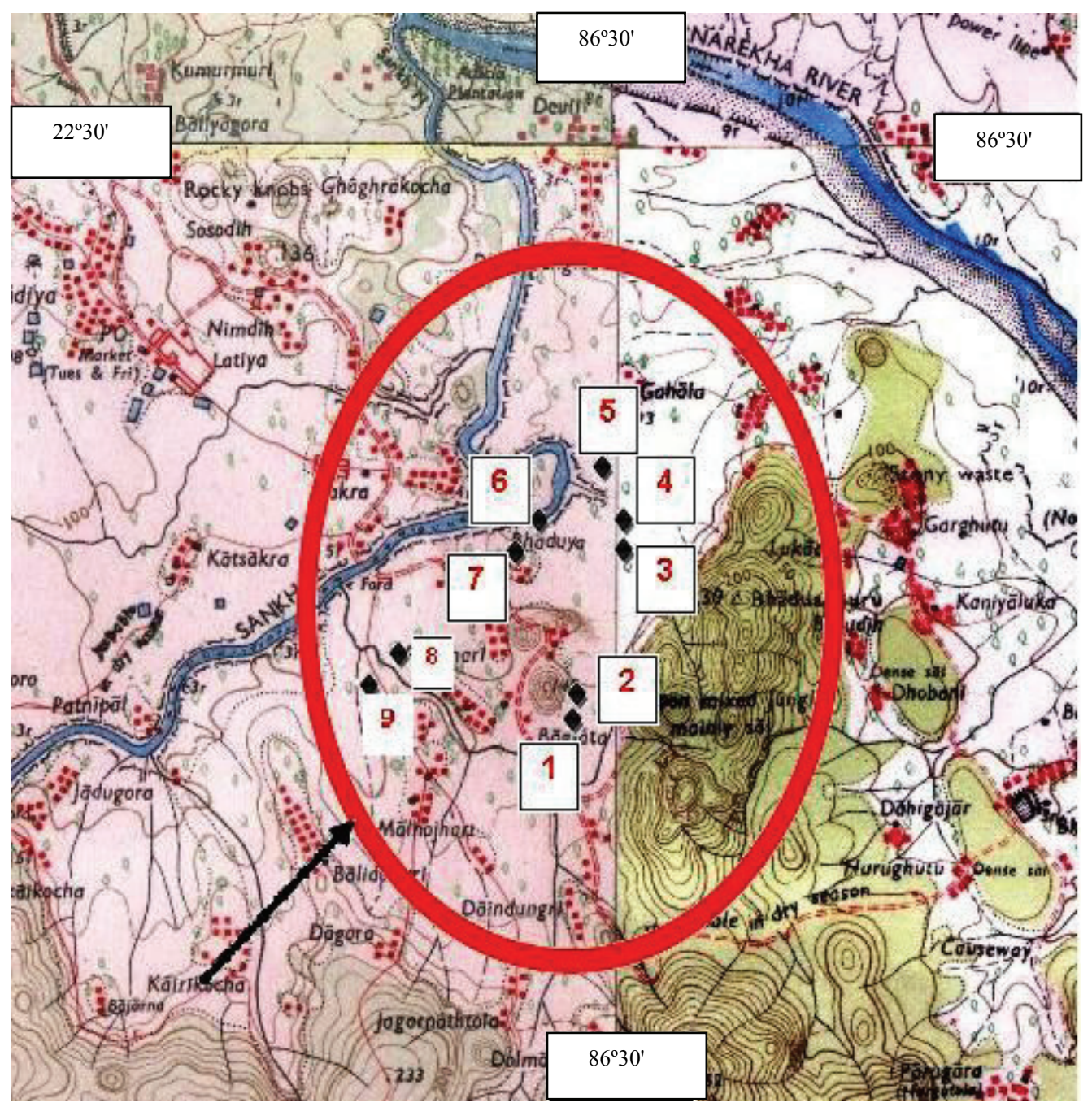

Figure 2. GPS measured sampling locations of Bagjata area, east Singhbhun, Jharkhand. 


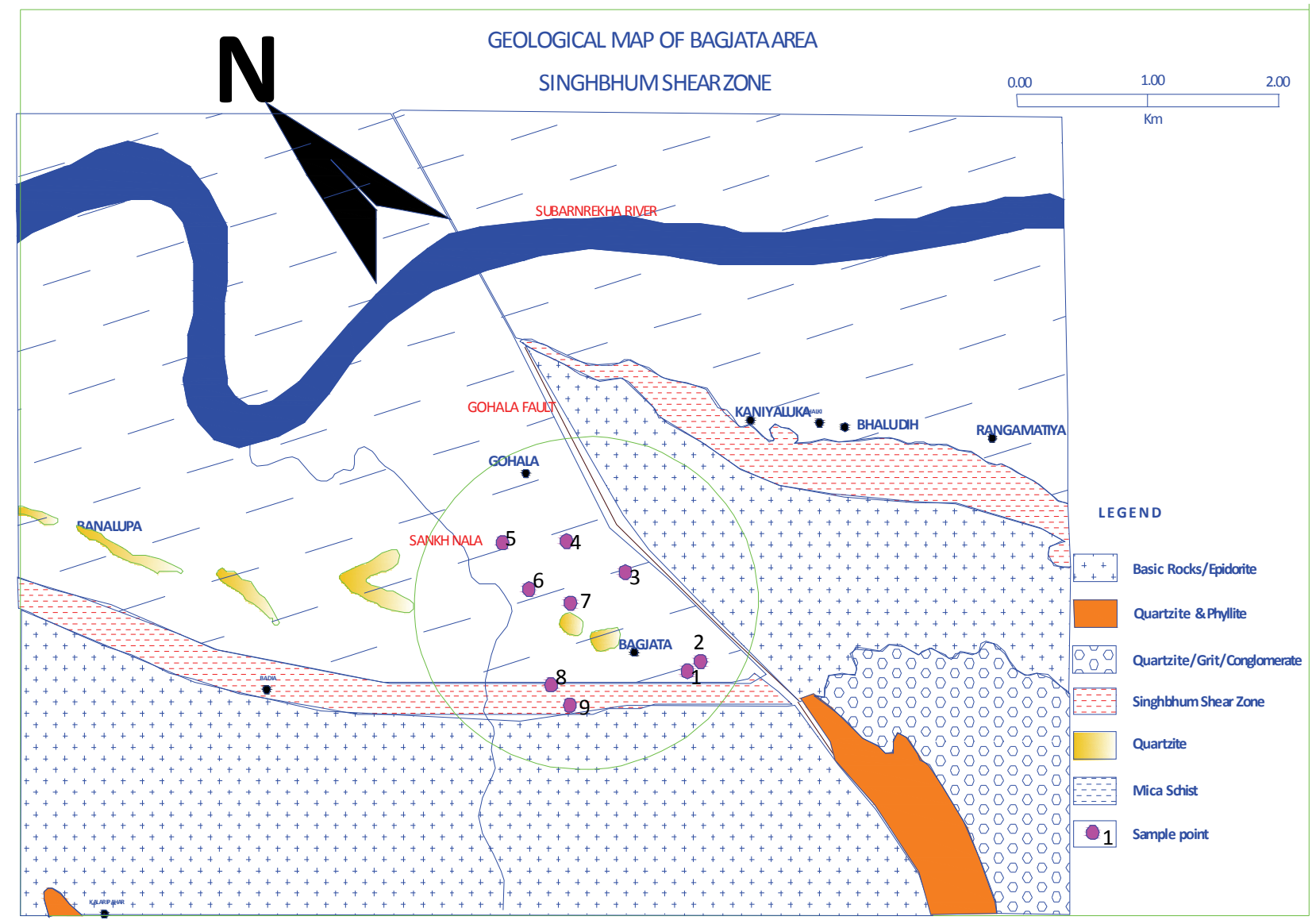

Figure 3. Location of collected samples plotted on the geological map, east Singhbhum, Jharkhand, India.

Table 2. Water table (AMSL) at bagjata area.

\begin{tabular}{cccc}
\hline Sample No & $\begin{array}{c}\text { Winter Season (Nov.) } \\
(\mathbf{m m})\end{array}$ & $\begin{array}{c}\text { Summer Season (May) } \\
(\mathbf{m m})\end{array}$ & $\begin{array}{c}\text { Rainy Season (July) } \\
(\mathbf{m m})\end{array}$ \\
\hline 1 & 4600 & 5870 & 1500 \\
2 & 680 & 3180 & 650 \\
3 & 1560 & 8830 & 1120 \\
4 & 5100 & 9370 & 1410 \\
5 & 1520 & 4450 & 1050 \\
6 & 1300 & 4000 & 1200 \\
7 & 2100 & 6580 & 1320 \\
9 & 7200 & 8600 & 2370 \\
\end{tabular}

of software Surfer 8.0 is done for contour generation. The collected samples were also analyzed for physical and chemical methods (Table 3). The $\mathrm{pH}$ of groundwater samples were measured at site using direct reading probe. Before taking reading $\mathrm{pH}$ meter was calibrated using a
$\mathrm{pH}=7$, buffer for natural water, single point calibration method. The other radicals for samples were analyzed in laboratories by chemical analysis methods. Radium analysis is carried out by batch adsorption from water sample. $133 \mathrm{Ba}$ is added to allow the measurement of 
the overall chemical yield by $\gamma$ counting. Radium is recovered with a few milliliters of $1.5 \mathrm{M} \mathrm{HCl}$, and lead is removed by a chromatographic column filled with Dowex $2 \times 8$. Finally $50 \mu \mathrm{g}$ of barium carrier is added, and the radium is co-precipitated as sulfate on a preformed bed of barium sulfate, to prepare a sample suitable for $\alpha$ and $\gamma$ counting.

\section{Groundwater Sampling:}

Sampling points are located based on the available open well position in the area and its durability to continue for a long period. The chosen well were monitored for a year in all the three seasons. Table 1 Shows the depth data measured in the three sea sons with respect to the respective reduced level in millimeter $(\mathrm{mm})$. The samples

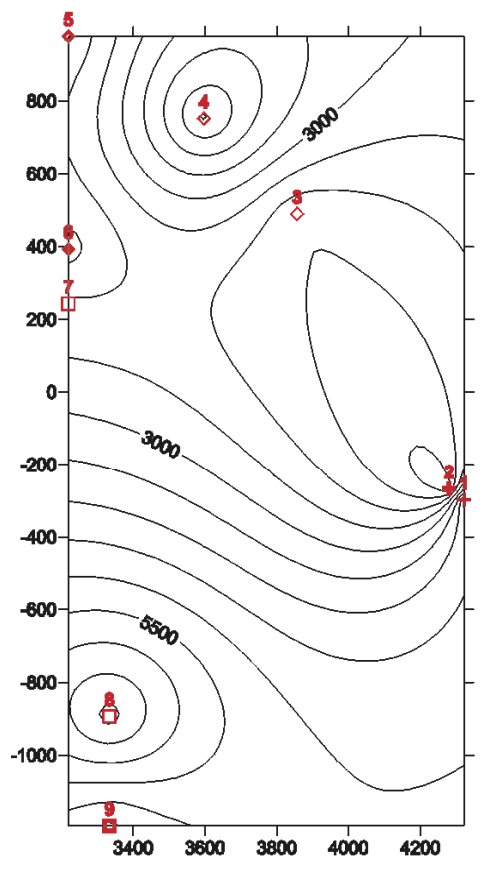

Second week of November (winter)

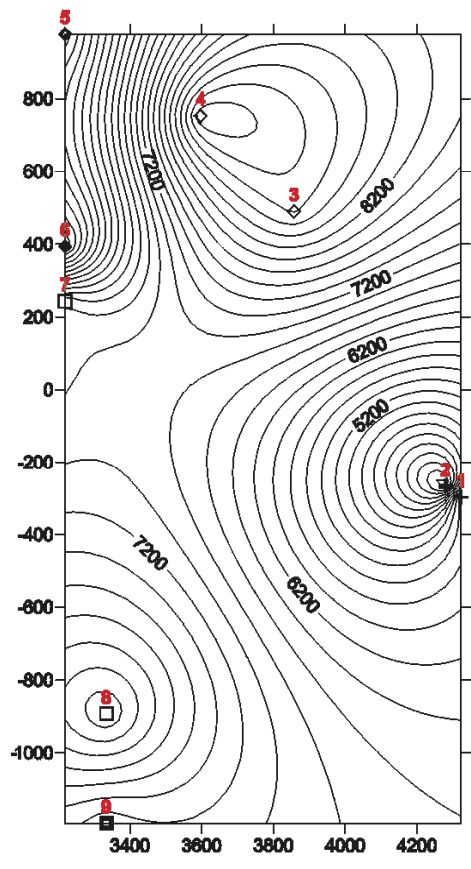

Third week of May (summer)

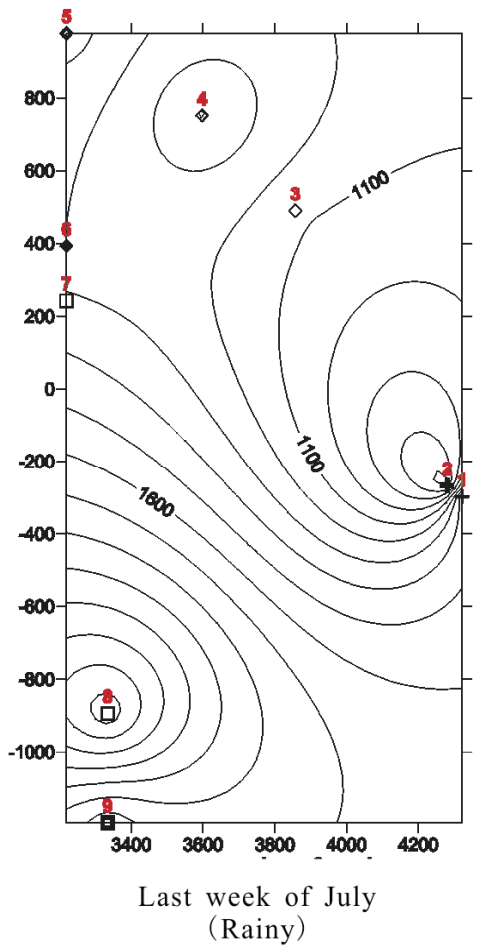

(Rainy)

Figure 4. Groundwater level contours at bagjata area, east singhbhum, Jharkhand.

Table 3. (a \& b) The chemical composition of groundwater around bagjata area collected during month november.

(a)

\begin{tabular}{|c|c|c|c|c|c|c|c|c|c|c|}
\hline $\begin{array}{c}\text { Sample } \\
\text { No }\end{array}$ & pH & $\begin{array}{c}\text { Total } \\
\text { Hardness } \\
\left(\mathrm{CaCO}_{3}\right), \\
\mathrm{mg} / \mathrm{L}\end{array}$ & $\begin{array}{l}\text { Iron } \\
\text { (Fe), } \\
\text { mg/L }\end{array}$ & $\begin{array}{c}\text { Chloride } \\
\text { (Cl), } \\
\text { mg/L }\end{array}$ & $\begin{array}{c}\text { Fluoride } \\
\text { (F), } \\
\mathbf{m g} / \mathbf{L}\end{array}$ & $\begin{array}{l}\text { Dissolved } \\
\text { solids, } \\
\text { mg/L }\end{array}$ & $\begin{array}{l}\text { Calcium } \\
\text { (Ca), } \\
\text { mg/L }\end{array}$ & $\begin{array}{c}\text { Magnesium } \\
\text { (Mg), } \\
\text { mg/L }\end{array}$ & $\begin{array}{l}\text { Copper } \\
\text { (Cu), } \\
\text { mg/L }\end{array}$ & $\begin{array}{c}\text { Manganese } \\
\text { (Mn), } \\
\text { mg/L }\end{array}$ \\
\hline 1 & 7.0 & 330 & 0.3 & 78 & 0.5 & 500 & 52 & 56 & $<0.01$ & 0.056 \\
\hline 2 & 7.2 & 326 & 0.5 & 68 & 0.4 & 356 & 26 & 26 & $<0.01$ & 0.024 \\
\hline 3 & 7.5 & 356 & 0.8 & 79 & 0.9 & 782 & 35 & 31 & $<0.01$ & 0.036 \\
\hline 4 & 7.2 & 358 & 0.4 & 64 & 0.2 & 300 & 45 & 21 & $<0.01$ & 0.058 \\
\hline 5 & 7.4 & 381 & 0.9 & 78 & 1.2 & 568 & 65 & 26 & $<0.01$ & 0.025 \\
\hline 6 & 7.0 & 415 & 1.2 & 124 & 0.7 & 986 & 35 & 33 & $<0.01$ & 0.014 \\
\hline 7 & 7.5 & 398 & 0.9 & 26 & 0.5 & 642 & 52 & 34 & $<0.01$ & 0.065 \\
\hline 8 & 7.0 & 425 & 0.7 & 63 & 0.9 & 564 & 25 & 11 & $<0.01$ & 0.082 \\
\hline 9 & 7.4 & 386 & 0.9 & 89 & 1.9 & 268 & 56 & 6 & $<0.01$ & 0.015 \\
\hline
\end{tabular}


(b)

\begin{tabular}{|c|c|c|c|c|c|c|c|c|c|c|}
\hline $\begin{array}{c}\text { Sample } \\
\text { No }\end{array}$ & $\begin{array}{c}\text { Sulphate } \\
\left(\mathrm{SO}_{4}\right), \\
\text { mg/L }\end{array}$ & $\begin{array}{c}\text { Nitrate } \\
\left(\mathrm{NO}_{3}\right), \\
\mathrm{mg} / \mathbf{L}\end{array}$ & $\begin{array}{c}\text { Arsenic } \\
\text { (As), } \\
\text { mg/L }\end{array}$ & $\begin{array}{l}\text { Lead } \\
(\mathbf{P b}), \\
\mathrm{mg} / \mathbf{L}\end{array}$ & $\begin{array}{l}\text { Zinc } \\
(\mathrm{Zn}), \\
\mathrm{mg} / \mathbf{L}\end{array}$ & $\begin{array}{c}\text { Chro- } \\
\text { mium } \\
\left(\mathbf{C r}^{6+}\right), \\
\mathrm{mg} / \mathbf{L}\end{array}$ & $\begin{array}{l}\text { Alumin- } \\
\text { ium (AI), } \\
\text { mg/L }\end{array}$ & $\begin{array}{c}\text { Boron } \\
\text { (B), } \\
\text { mg/L }\end{array}$ & 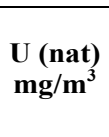 & $\begin{array}{c}\text { Ra- } \\
\underset{\operatorname{dium}}{\mathbf{d i u}^{226)}}(\mathbf{R} \\
\mathbf{B q} / \mathbf{m}^{3}\end{array}$ \\
\hline 1 & 56 & 5 & $<0.02$ & $<0.05$ & 0.035 & $<0.01$ & $<0.01$ & $<0.1$ & 2.5 & 25 \\
\hline 2 & 6 & 12 & $<0.02$ & $<0.05$ & 0.08 & $<0.01$ & $<0.01$ & $<0.1$ & 3.5 & 36 \\
\hline 3 & 58 & 35 & $<0.02$ & $<0.05$ & 0.06 & $<0.01$ & $<0.01$ & $<0.1$ & 4.0 & 41 \\
\hline 4 & 59 & 5 & $<0.02$ & $<0.05$ & 0.058 & $<0.01$ & $<0.01$ & $<0.1$ & 2.6 & 32 \\
\hline 5 & 87 & 68 & $<0.02$ & $<0.05$ & 0.069 & $<0.01$ & $<0.01$ & $<0.1$ & $<0.5$ & 12 \\
\hline 6 & 125 & 34 & $<0.02$ & $<0.05$ & 0.042 & $<0.01$ & $<0.01$ & $<0.1$ & $<0.5$ & 25 \\
\hline 7 & 56 & 26 & $<0.02$ & $<0.05$ & 0.026 & $<0.01$ & $<0.01$ & $<0.1$ & $<0.5$ & 14 \\
\hline 8 & 36 & 6 & $<0.02$ & $<0.05$ & 0.085 & $<0.01$ & $<0.01$ & $<0.1$ & 0.8 & 18 \\
\hline 9 & 89 & 11 & $<0.02$ & $<0.05$ & 0.062 & $<0.01$ & $<0.01$ & $<0.1$ & 1.6 & 23 \\
\hline
\end{tabular}

were also collected from these chosen open well during the winter (November) season. The Poly-ethylene bottles are used for sample collection. Each sample bottle is identified by date, site name and an adhesive bar-code label. The bar-code allows each sample to be tracked through sample analysis and data entry. All bottles for sampling were given the unique bar-code identification number. Collected samples were protected by reducing temperature method to avoid any further contamination, loss or other unintended changes. The sample bottles were completely filled to avoid any evaporation loss. Raw data for all analyses are entered into a Visual dBase database.

\section{Hydro-Geochemical Characteristics}

The chemical composition of Ground water is shown Table 2. The $\mathrm{pH}$ of water samples collected from Bagjata area is mildly alkaline to natural. The most of radicals falls within the permissible limit of drinking water except the Iron content at few locations. The presence of radioactivity is purely due to the Uranium mineral rich area. This value is far beyond the radium activity admissible for drinking waters.

\section{Discussion and Conclusions}

The collected samples were analyzed for groundwater position, its fluctuation in respect of seasonal variation. Data were first analyzed through manual formation of reduced level and then schematic drawing is formulated with the help of the software for contour generation. Figure 4(a) shows the ground water contour during the winter season where maturity in the domain can be seen easily. Figure 4(b) is the contour diagram of summer season, the dense contour reflects to the scarcity of water in the ground water domain and thus velocity is fast. Figure 4(c) is the contour diagram for rainy season. Again a maturity in the horizon is returned back. Since at any point the water table equals the energy head as a consequence, flow lines lie perpendicular to water table contours. Therefore in all the three season the direction of ground water movement is parallel and sub parallel to North direction which is the direction of Gohala Fault. Gohala Fault is the major discontinuity in the area. Authors find the groundwater movement is very much controlled by the Gohala Fault which is lying along in the N-S direction. Also the wide contour intervals show the higher permeabilities than those of the narrower spacing. Therefore prospects for a good yielding well are better in rainy and winter seasons respectively than in the summer session.

Also the major discontinuity in the area that is Gohala fault is very much controlling the flow direction. Authors observe an effluence type of discharge of groundwater where it is in a position to recharge/feed the rivers during all the three seasons. Groundwater quality is mildly alkaline to natural. Radioactive contamination in water is very low and much below the limit. Other radicals are also within the permissible limits and designated safe for drinking. Further it envisages the necessity of such study being undertaken in the entire SSZ belt to secure precise information about the surface manifestations which govern the groundwater recharge potentiality as well as its quality.

\section{Acknowledgements}

The authors are thankful to the C.M.D. Mr. R. Gupta and Mr. A.K.Sarangi T.S. to the C.M.D. of the Uranium 
Corporation of India Limited (a Govt. of India Undertaking) at Jaduguda near Jamshedpur for their support and encouragement rendered during the course of the fieldwork. The kind co-operation and necessary infrastructural facilities provided by the Head of the University Department of Geology, Ranchi University, Ranchi (Jharkhand, India) is thankfully acknowledged.

\section{References}

[1] A. K. Bannerji, "Cross Folding Migmatisation and Ore Location along Part of the Singhbhum Shear Zone, South of Tatanagar, Bihar," Economic Geology, Vol. 57, No. 1, 1962 pp. 50-71.

[2] S. B. Bhattacharjee, A. K. Ghosh, L. Bhattacharjee and S. R. Svananda, "Uranium Mineralisation and Trace Element Distribution in the Jaduguda Uranium Deposit, Singhbhum Thrust Belt, Bihar, Contributions to the Geology of Singhbhum," Jadavpur University, Calcutta, 1966, pp. 59-75.

[3] S. B. Bhattacharjee, A. K. Ghosh, L. Bhattacharjee and S.
Bhattacharjee, "Minor Elements in Some Rocks and Minerals of the Rakha Mines Area, Singhbhum, India," Mineralogical Magazine, Vol. 36, No. 281, 1968, pp. 671675.

[4] K. L. Bhola, G. R. Udas, N. R. Mehta and G. H. Sahasrabudhe, "Uranium Ore Deposits at Jaduguda in Bihar State India," In: Peaceful Uses of Atomic Energy, Proceedings of Second Internet Conference, Vol. 2, 1958, pp. 704-708.

[5] J. A. Dunn and A. K. Dey, "Geology and Petrology of Eastern Singhbhum and Surrounding Areas," Memoirs of Geological Survey, India, Vol. 69, No. 2, 1942.

[6] J. M. McDonald and A. W. Harbaugh, "A Modular Three-Dimensional Finite-Difference Groundwater Flow Model. Techniques of Water Resources Investigations of U.S.," Geological Survey Book, 1988, p. 586.

[7] H. M. Ragunah and D. K. Todd, "Ground Water," In: H. M. Raghunath and D. K. Todd, Eds.

[8] S. C. Sarkar, "Geology and Ore Mineralisation of the Singhbhum Copper-Uranium Belt, Eastern India," INA Press, Kolkata, 1985. 